\title{
ANALISIS PROMOTION MIX PADA PRODUK SIDIK FATHONAH DI BMT NU CABANG GANDING
}

\author{
Ach. Zuhri ${ }^{1}$ \\ ${ }^{1}$ Manajemen, Universitas Bahaudin Mudhary Madura \\ e-mail: achzuhri3@gmail.com
}

\begin{abstract}
This research method uses a qualitative approach, the informants are employees of Baitul Maal wat Tamwil (BMT) NU Ganding Branch. While the data collection techniques are by interview, observation, and documentation. The results showed that first; The promotion mix variable has been applied in the BMT NU Ganding Branch, advertising in the form of banner installation and browser distribution, sales promotion by going directly to the demonstration of SIDIK Fathonah products to students, publicity by holding lectures during the Annual Member Meeting (RAT) and reporting of activities and products in NU's online media, and personal selling by visiting and talking directly with the principal and parents of the closest students. Second; strengths, that is with the silaturrahim network strategy and personal approach, weaknesses, lack of manpower, reporting and advertising are too universal, opportunities, opening of legislation and strategic location of offices, and threats, inadequate technology and the emergence of more and more competitors with innovation promotions that are getting better and can adjust to the circumstances and needs around.
\end{abstract}

Keywords: Advertising, Marketing Mix, Personal Sales, Publicity, Sales promotion.

\begin{abstract}
Abstrak
Penelitian ini menggunakan metode pendekatan kualitatif, informan adalah karyawan Baitul Maal wat Tamwil (BMT) NU Cabang Ganding. Sedangkan tehnik pengumpulan datanya yaitu dengan observasi, wawancara, dan
\end{abstract}


dokumentasi. Hasil penelitian menunjukkan bahwa pertama; Variabel promotion mix sudah diterapkan di BMT NU Cabang Ganding, advertising (periklanan) berupa pemasangan spanduk dan penyebaran browsur, sales promotion dengan cara mendatangi langsung serta melakukan demonstrasi produk SIDIK Fathonah kepada para siswa, publicity dengan cara mengadakan pengajian saat Rapat Anggota Tahunan (RAT) dan pemberitaan kegiatan dan produk di media online NU, dan personal selling dengan mendatangi dan berbicara langsung dengan kepala sekolah dan orang tua siswa terdekat. Kedua; kekuatan, yaitu dengan strategi jaringan silaturrahim dan pendekatan personal, kelemahan, minimnya tenaga kerja, pemberitaan dan periklanan terlalu universal, peluang, terbukanya peraturan perundang-undangan dan letak kantor yang strategis, dan ancaman, teknologi yang dimiliki kurang memadai dan munculnya pesaing yang semakin banyak dengan inovasi promosi yang semakin bagus dan bisa menyesuaikan dengan kondisi dan kebutuhan sekitar.

Kata kunci : Bauran Pemasaran, Penjualan Pribadi, Periklanan, Publisitas, Sales Promosi. 


\section{A. PENDAHULUAN}

Terdapat tiga fungsi utama dari Bank syariah yaitu menghimpun dana dari masyarakat dalam bentuk titipan dan investasi, menyalurkan dana kepada masyarakat yang membutuhkan dana dari bank, dan memberikan pelayanan jasa perbankan Syariah (Ismail, 2001). Jenis usaha bank syariah selaku lembaga keuangan perantara (intermediary) secara simple dapat dijalankan ke dalam bank melalui kegiatan mengumpulkan dana disebut dengan funding. Sementara kegiatan memanifestasikan dana kepada masyarakat oleh bank disebut dengan kegiatan pembiayaan (financing) atau lending (Muhammad, 2004).

Strategi pemasaran merupakan metode yang dijalani perusahaan untuk menjalankan misi, tujuan, sasaran yang telah ditetapkan dengan menjaga dan mengusahakan adanya keselarasan antara beberapa tujuan yang ingin dicapai, keahlian yang dimiliki serta peluang dan ancaman yang dihadapi di pasar produknya.

Strategi diperlukan untuk memenangkan kompetisi sehingga diperoleh tingkat penjualan dan profit yang memadai sesuai dengan risiko yang dihadapi. Strategi berusaha untuk mengatasi keterbatasan yangdihadapi perusahaan dan mampu memanfaatkan berbagai sumberdaya yang dimiliki secara optimal (Adisaputro, 2014).

Dalam pemasaran modern, promosi adalah strategi yang paling akrab digunakan oleh berbagai bisnis organisasi untuk memikat pelanggan (Kumar \& Patra, 2017). Salah satu faktor penting dalam mencapai kesuksesan suatu pemasaran yaitu promosi. Betapapun bagusnya kualitas suatu produk, jika konsumen belum pernah mengetauinya dan tidak begitu yakin bahwa produk tersebut akan bermanfaat bagi konsumen, maka konsumen tidak akan membeli dan menggunakannya (Subagyo, 2010). Menurut (Karunanithy \& Sivesan, 2013), tujuan promosi adalah untuk menjangkau konsumen yang ditargetkan dan membujuk mereka untuk membeli. 
Bauran pemasaran merupakan faktor penentu dalam menunjang keberhasilan suatu produk agar supaya melekat di fikiran nasabah (Haris, 2011). Salah satu teknik promotion mix yaitu penjualan pribadi, penjualan pribadi merupakan suatu metode promosi yang disampaikan secara lisan dan bersifat persuasif baik kepada calon nasabah untuk mewujudkan terciptanya transaksi yang saling menguntungkan antara kedua belah pihak, tentunya dengan menggunakan manusia sebagai alat promosinya. BMT NU merupakan salah satu BMT terbesar di jawa timur yang mengedepankan pelayanan yang berkualitas baik. Berdasarkan observasi awal, para karyawan di BMT NU cabang Ganding aktif sekali melakukan konsep personal selling dengan mendatangi sendiri ke tempat nasabah maupun calon nasabah, baik ke rumah, sekolah, bahkan ke pasar-pasar tetap mereka masuki.

Berdasarkan tujuan dari BMT sendiri yang mengharuskan untuk mampu memberikan solusi bagi masyarakat menengah ke bawah membuat BMT NU, BMT NU melakukan inovasi-inovasi guna meringakan beban masyarakat di bidang keuangan, termasuk biaya sekolah anak. BMT NU menyediakan suatu produk yaitu Simpanan Pendidikan (SIDIK) Fathonah yang memudahkan orang tua siswa atau siswa untuk menyimpan uangnya dengan keuntungan bagi hasil yang cukup tinggi, yaitu 45\%. Dengan menggunakan akad Mudharabah Muthlaqah yang dapat disetor kapan saja dan dapat ditarik pada saat tahun ajaran baru dan semesteran dengan setoran awal Rp. 2.500 dan setoran selanjutnya minimal Rp. 500 membuat para siswa yang ada tertarik untuk menabung.

Qusyairy selaku ketua BMT NU cabang ganding mengatakan "Tujuan dari simpanan pendidikan Fathonah ini tidak lain yaitu untuk membantu siswa atau orang tua siswa yang ingin meraih cita-cita secara sempurna." Ungkapnya. Meskipun produk yang ditawarkan sudah cukup menarik, ternyata nasabah yang menggunakan produk SIDIK Fathonah masih sedikit, seperti yang dikatakan Qusyairy, "Masalahnya mas yang menggunakan simpanan SIDIK Fathonag masih sangat sedikit di sini." Tambahnya. 
Tujuan dari penelitian ini yaitu untuk mengetahui implementasi promotion mix pada produk SIDIK Fathonah di BMT NU Cabang Ganding menggunakan Analisis SWOT.

\section{B. METODE PENELITIAN}

Penelitian ini menggunakan pendekatan kualitatif dengan jenis penelitian lapangan, artinya penelitian ini dilakukan di lokasi penelitian. Adapun lokasi penelitian ini yaitu di BMT BMT NU Cabang Ganding yang berada di Jl. Raya Lenteng, Talambung Laok, Ganding, Kabupaten Sumenep, Jawa Timur 69462.

Teknik pengumpulan data yang peneliti gunakan yaitu 1) observasi: observasi yang peneliti gunakan yaitu observasi terang-terangan dan tersamar, karena peneliti ingin lebih mudah dalam mendapatkan data dengan mendatangi dan mengatakan langsung kepada objeknya. Kemudian peneliti akan menngobservasi secara tersamar untuk menganalisa proses pelalyanan yang sebenarnya terjadi di lapangan. 2) Wawancara; objek yang peneliti wawancarai di antaranya karyawan, nasabah dan keluarga nasabah. 3) Dokumentasi: tujuan dari dokumen ini yaitu untuk mengumpulkan data tambahan melalui website dan sebagainya.

Analisis data yang peneliti gunakan yaitu dengan cara mencatat, memilahmilah, dan mensintesiskan data, membuat pola, memilih mana yang penting dan yang akan dipelajari, kemudian membuat kesimpulan yang mudah difahami yang akan diinformasikan kepada orang lain.

\section{HASIL DAN PEMBAHASAN}

Promotion mix terdapat empat macam elemen yang bisa digunakan oleh bank dalam mempromosikan baik produk maupun jasanya. Pertama, melalui periklanan (Advertising). Kedua, melalui promosi penjualan (sales promotion). Ketiga, melalui publisitas (publicity), dan keempat melalui penjualan pribadi (personal selling) (Kasmir, 2010). 


\section{Implementasi Promotion Mix}

Pertama, teknik advertising sudah dilakukan oleh BMT NU Cabang Ganding dengan memasang spanduk, menyebarkan brosur-brosur kepada nasabah yang dalam hal ini mahasiswa, juga sudah diupload di media BMT NU, namun Teknik advertising yang dilakukan masih tergolong kurang detail karena iklannya menjelaskan BMT NU secara umum.

Kedua, metode sales promotion sudah juga dilakukan oleh BMT NU Cabang Ganding dengan mendatangi sekolah-sekolah dan bahkan melakukan demonstrasi produk SIDIK Fathonah kepada para siswa, namun hal ini kurang optimal karena kurangnya tenaga kerja, di mana yang bertugas sebagai marketing di bidang tabungan hanya satu orang yaitu Azizah.

Ketiga, kegiatan publicity yang dilakukan oleh BMT NU Cabang Ganding saat ini dengan cara mengadakan pengajian bersama anggota pada saat RAT, dan pemberitaan tentang kegiatan dan produk BMT NU di media online NU, namun publicity masih kurang maksimal karena pemberitaan tentang produk-produknya yang dalam hal ini produk SIDIK Fathonah masih sangat sedikit dari pada prestasi dan kegiatan lainnya.

Keempat, teknik personal selling sudah dilakukan oleh BMT NU Cabang Ganding dengan mendatangi dan berbicara secara langsung kepada kepala sekolah dan orang tua siswa, namun hal ini hanya dilakukan satu kali tanpa ada tindak lanjut dari pihak BMT NU Cabang Ganding dan orang tua siswa yang didatangi hanya orang tua siswa yang berada di sekitar rumah Azizah.

Hasil ini sesuai dengan penelitian yang dilakukan oleh Abdullah yang menunjukkan bahwa secara statistik terdapat pengaruh yang signifikan elemen bauran promosi (Advertising, Sales promotion, Publicity, dan Personal selling) terhadap keputusan pembelian konsumen (Abdullah, 2016). Namun, berbeda dengan penelitian yang dilakukan oleh Nour yang menunjukkan bahwa tidak ada pengaruh yang signifikan dari aktifitas bauran promosi (Advertising, Sales promotion, Publicity, dan Personal selling) yang dilakukan 
oleh pemegang saham perusahaan keramik dan kaca Yordania terhadap keputusan pembelian konsumen (Nour et al., 2014).

\section{Analisis SWOT dari Implementasi Promotion Mix}

Pertama Streengts. 1) Menggunakan strategi jaringan silaturahmi yang bertujuan untuk mempererat hubungan antara pihak BMT NU dengan para masyarakat dan anggota BMT NU Cabang Ganding. Marketing BMT NU Cabang Ganding datang ke rumah-rumah anggota atau ke sekolah-sekolah melakukan sosialisasi produk yang dimiliki BMT NU, dengan begitu anggota mungkin akan tertarik dengan salah satu produk yang ditawarkan. 2) Yaitu dengan cara pendekatan secara personal kepada calon anggota dan anggota. Marketing di BMT NU Cabang Ganding dengan cara pendekatan yaitu datang ke sekolah melakukan komunikasi kepada anggota, jadi marketing mengetahui karakter anggota dan kemampuan anggota untuk menabung. Menjaga hubungan baik dengan anggota meski diluar lingkungan kerja.

Kedua Weakness. 1) Minimnya tenaga kerja. BMT NU Cabang Ganding hanya mempunyai satu karyawan yang bertugas sebagai marketing dibidang tabungan, hal ini membuat marketing tersebut kewalahan dalam memasarkan produknya. 2) Pemberitaan yang kurang banyak dalam bidang keunggulan produk. Dalam hal publicity, BMT NU Cabang Ganding masih memberitakan BMT NU secara umum, seperti kegiatan perekrutan anggota dan penghargaan, BMT NU seharusnya juga mengimbanginya dengan pemberitaan tentang keunggulan produk dan capaian produk. 3) Teknik

advertising terlalu universal. BMT NU Cabang Ganding dalam mempromosikan produknya melalui advertising menggunakan spanduk dan brosur, tapi Bahasa yang ada dalam spanduk dan browser tersebut masih terlalu umum (kurang detail), seperti halnya produk-produknya yang hanya dijelaskan pengertian dan tujuannya saja.

Ketiga Opportunities. 1) Peraturan perundang-undangan yang terbuka luas, berbagai peluang untuk mengembangkan produk-produk BMT. Peluang 
pengembangan produk yang dimiliki oleh BMT NU Cabang Ganding selalu berinovasi untuk mengembangkan produk yang sudah ada dan menarik minat nasabah untuk memilih produknya. 2) Letak BMT NU Cabang Ganding sangat strategis karena berada di dekat pasar, sekolah dan pemukiman warga memberikan peluang yang besar bagi BMT NU Cabang ganding untuk terus berkembang. BMT NU Cabang Ganding diuntungkan dengan letak yang strategis sehingga memudahkan anggota untuk datang ke BMT NU Cabang Ganding untuk bertransaksi.

Keempat Treats. 1) Tekhnologi yang dimiliki BMT NU Cabang Ganding kurang atau tidak memadai. BMT NU tekhnologi yang dimiliki kurang memadai dikarenakan kurangnya dana, seperti bank-bank yang sudah memiliki ATM dan mempunyai aplikasi mobile banking yang memudahkan nasabah dalam bertransaksi. 2) Munculnya pesaing yang semakin banyak dengan inovasi promosi yang kian baik dan yang bisa menyesuaikan dengan keadaan dan kebutuhan lingkungan yang ada di sekitar BMT NU Cabang Ganding.

\section{KESIMPULAN}

Teknik advertising dilakukan oleh BMT NU Cabang Ganding dengan memasang spanduk, menyebarkan brosur-brosur kepada nasabah yang dalam hal ini mahasiswa, juga sudah diupload di media BMT NU. Teknik sales promotion sudah juga dilakukan oleh BMT NU Cabang Ganding dengan cara mendatangi sekolahsekolah dan bahkan melakukan demonstrasi produk SIDIK Fathonah kepada para siswa. BMT NU Cabang Ganding saat ini menggunakan Teknik publicity dengan cara mengadakan pengajian bersama anggota pada saat RAT, dan pemberitaan tentang kegiatan dan produk BMT NU di media online NU. Dan untuk personal selling, BMT NU Cabang Ganding menggunakannya dengan cara mendatangi dan berbicara secara langsung kepada kepala sekolah dan orang tua siswa yang rumahnya tidak jauh dari rumah (tetangga) marketing tabungan (Azizah). 
Analisis SWOT dari implementasi Promotion Mix pada BMT NU Cabang Ganding antara lain, kekuatan (streengts): Menggunakan strategi jaringan silaturahmi yang bertujuan untuk mempererat hubungan antara pihak BMT NU dengan para masyarakat dan anggota BMT NU Cabang Ganding, dan dengan cara pendekatan secara personal kepada calon anggota dan anggota. Kelemahan (weakness): Minimnya tenaga kerja, pemberitaan yang kurang banyak dalam bidang keunggulan produk, dan teknik advertising terlalu universal. Peluang (opportunities): Letak BMT NU Cabang Ganding sangat strategis karena berada di dekat pasar, sekolah dan pemukiman warga. Dan ancaman (treats): Tekhnologi yang dimiliki BMT NU Cabang Ganding kurang atau tidak memadai dan munculnya pesaing yang semakin banyak dengan inovasi promosi yang kian baik dan yang bisa menyesuaikan dengan keadaan dan kebutuhan lingkungan sekitar.

\section{DAFTAR RUJUKAN}

Abdullah, J. A. (2016). The Impact of Promotional Mix Elements on Consumers Purchasing Decisions. Journal for Studies in Management and Planning, 02(01). Adisaputro, G. (2014). Manajemen pemasaran (analisis untuk perancangan strategi pemasaran). Unit Penerbit dan Percetakan STI Manajemen YKPN.

Haris, M. A. (2011). Analisis Pelaksanaan Promotion Mix pada OMUS Yogyakarta, Skripsi, Prodi Ilmu Komunikasi. Universitas Islam Negeri Sunan Kalijaga Yogyakarta.

Ismail. (2001). Perbankan Syariah. Kencana.

Karunanithy, M., \& Sivesan, S. (2013). An Empirical Study on the Promotional Mix and Brand Equity: Mobile Service Providers. Industrial Engineering Letters, $3(3)$.

Kasmir. (2010). Pemasaran Bank (Revisi). Kencana.

Kumar, S., \& Patra, S. (2017). Does Promotion Mix Really help to Enchance Brand Equity: A Literature Review. Indian Journal of Commerce \& Management Studies, VIII(2). 
http://ejurnal.budiutomomalang.ac.id/index.php/ecoducation

Muhammad. (2004). Manajemen Dana Bank Syariah. Ekonisia.

Nour, M. I., Almahirah, mohammad salamh, Said, S. "Mohammed, \& Freihat, S. (2014). The Impact of Promotional Mix Elements on Consumers Purchasing Decisions. International Business and Management, 8(2). https://doi.org/10.3968/4800

Subagyo, A. (2010). Marketing in Business Studi Kasus UMK \& LKM (Usaha Mikro Kecil \& Lembaga Keuangan Mikro). mitra wacana media. 